\title{
Wetsvoorstel deskundige in strafzaken
}

\author{
J. Hielkema*
}

Een van de doelstellingen van het wetsvoorstel deskundige in strafzaken ${ }^{1}$ is de verbetering van de kwaliteitszorg met betrekking tot deskundigen in het strafproces. Zal de invoering van deze beoogde wet daar inderdaad toe leiden? Zal deze wet leiden tot een zorgvuldiger proces van waarheidsvinding (feitenvaststelling; controle; verantwoording)? In deze bijdrage geef ik een beknopte weergave van de punten die tijdens de bijeenkomst van Lutje PJG op 18 september 2008 aan de orde zijn geweest.

\section{De hoofdlijnen van het wetsvoorstel}

De wetgever heeft een aantal in de voorbije jaren in de literatuur en rechtspraak aangedragen zorgpunten over strafrechtelijke waarheidsvinding 'opgepikt' en een wetsvoorstel Deskundigen in strafzaken ingediend. De inhoud en vorm van het wetsvoorstel zijn ingegeven door onder andere het rapport Strafvordering 2001 dat mede door medewerkers van de vakgroep Strafrecht van de universiteit Groningen is geschreven. Kwakman heeft in het desbetreffende deelrapport een aantal aanbevelingen gedaan. ${ }^{2}$ De Minis-

* Jelte Hielkema was tot 1 oktober 2008 als UD verbonden aan de vakgroep Strafrecht en Criminologie van de RUG en is sinds die datum raadsheer in het gerechtshof Leeuwarden.

1 Kamerstukken 31116 (Wijziging van het Wetboek van Strafvordering tot verbetering van de regeling van de positie van de deskundige in het strafproces (Wet deskundige in strafzaken). Inmiddels is het wetsvoorstel tot wet verheven, maar moet zij nog wel in werking treden: zie Wet van 22 januari 2009, Stb. 2009, 33.

2 N.J.M. Kwakman, De deskundige in het strafproces, in: M.S. Groenhuijsen \& G. Knigge (red.) Het onderzoek ter zitting. Eerste interimrapport Strafvordering 2001, z.p.: KUB/RUG, z.j., p. $343 \mathrm{ev.}$ 
ter van Justitie schrijft dat hij die voorstellen in grote lijnen heeft overgenomen.

Het wetsvoorstel beoogt de regeling voor de deskundige te verbeteren. Het heeft een drietal doelstellingen: het verbeteren van de regeling voor de deskundige door aan hem een eigen positie met rechten en plichten toe te kennen, het versterken van de positie van de verdediging en in de derde plaats het mogelijk maken van het stellen van kwaliteitseisen aan verschillende groepen deskundigen.

Het Wetboek van Strafvordering wordt daartoe op drie onderdelen aangevuld. Er komt in het eerste Boek een afzonderlijke titel met de rechten en plichten van de deskundige tijdens het voorbereidend onderzoek en het onderzoek op de terechtzitting (artikel $51 \mathrm{i}$ tot en met $51 \mathrm{~m} \mathrm{~Sv}$.). Er komt een uitwerking van de regeling voor de benoeming van een deskundige door de officier van justitie in het voorbereidend onderzoek en van de positie van de verdediging bij het vragen om een deskundigenonderzoek of een tegenonderzoek (artikel 150, 150a en 150b Sv.). Bovendien bevat het wetsvoorstel een herziening van de huidige bepalingen betreffende de inschakeling van deskundigen in het gerechtelijk vooronderzoek, welke regeling voorts buiten het verband van het gerechtelijk vooronderzoek door de rechter-commissaris kan worden toegepast (art. $176 \mathrm{~Sv}$.)

\section{Enkele algemene en specifieke punten van kritiek}

Er is enige reden tot kritiek op zowel het wetsvoorstel als geheel als op een aantal conceptartikelen of clusters daarvan. ${ }^{3}$ Voor wat betreft het voorstel als geheel: er staat maar een beperkte visie in de Memorie van Toelichting over het strafproces als procedure naar het onderzoek van de feiten en welke rol de deskundige daarbij speelt.

Voor wat betreft de artikelen: het wetsvoorstel maakt een weinig onderbouwd onderscheid tussen technisch onderzoek en deskundigenonderzoek

3 Voor andere meer of minder kritische besprekingen, zie bijvoorbeeld M. J. Dubelaar en J.F. Nijboer 'De deskundige en de waarheid. Een nadere beschouwing over enkele aspecten van de toekomstige Wet deskundigen in strafzaken'. Delikt en Delinkwent, 2008, 9, p. 966-983; G. Haverkate, 'Het voorstel voor de Wet deskundige in strafzaken', Expertise en Recht, 2008, afl. 1, p. 17-26; N.J.M. Kwakman 'De derde weg', Trema, 2008, afl. 8, p. 357-362. 
(art. 150k lid 2). Het wetsvoorstel staat de officier van justitie toe om in het belang van het onderzoek ambtshalve of op verzoek van de verdachte deskundigenonderzoek te laten verrichten (art. 150k lid 1). De hulpofficier mag dat ook, zij het dat diens bevoegdheid is beperkt tot 'technisch onderzoek'. De minister heeft aangekondigd dat het onderscheid via lagere regelgeving nader zal worden toegelicht en uitgewerkt, maar het is de vraag of het onderscheid in de praktijk toepasbaar is. Wat is (nog) wel technisch onderzoek en wat niet (meer)? Bovendien is onduidelijk welke consequenties de rechter dient te verbinden of mag verbinden aan schending van dat voorschrift. Voorts mag de officier van justitie alleen geregistreerde deskundigen inschakelen (art. 150k lid 1), anders dient hij of zij zich tot de rechter(commissaris) te wenden. Ik veronderstel dat die bepalingen in de praktijk niet letterlijk zullen worden nageleefd. Strikte naleving zou ertoe leiden dat telkens als de officier van justitie een 'incidentele' deskundige zou willen inschakelen, hij steeds van de rechter-(commissaris) zal moeten vorderen dat die een deskundige benoemt. Ik geef toe dat de inschakeling van incidentele deskundigen geen schering en inslag lijkt te zijn, maar ik acht deze voorwaarde overbodig. De wet, jurisprudentie en - hopelijk - ook de praktijk voorzien in betere controle-instrumenten in zo'n geval: vragen naar de deskundigheid van de deskundige en de betrouwbaarheid en geldigheid van de gehanteerde methode, alsmede de mogelijkheid om de desbetreffende door of via een rechter te horen. Indien men de Nota van Toelichting bij de concept-Algemene Maatregel van Bestuur inzake kwaliteitseisen aan deskundigen in strafzaken (hierna: de concept-AMvB) leest (p.1), blijkt dan ook dat de minister er toch rekening mee houdt dat het Openbaar Ministerie andere dan geregistreerde deskundigen zal inschakelen.

Voorts is het de vraag in welke zin de positie van de verdediging in het vooronderzoek werkelijk wordt verbeterd. De verdediging krijgt niet meer financiële armslag dan nu (voor de huidige regelingen zie men bijv. art. 591 Sv. en art. 16 Wet tarieven in strafzaken) en zij blijft afhankelijk van de medewerking van andere procesdeelnemers. Wil de verdachte zelf - buiten de bemoeienis van Openbaar Ministerie en rechters om - deskundigen inschakelen dan moet hij die kosten in eerste instantie zelf betalen. Is de uitkomst van dat deskundigenonderzoek voor hem gunstig, dan kan hij op voet van art. $591 \mathrm{~Sv}$. na afloop van de strafprocedure om een vergoeding van de kosten vragen. Maar dan moet de rechter die kosten in het belang van het onderzoek achten. Is de uitkomst van dat deskundigenonderzoek voor de verdachte ongunstig, dan zal hij het desbetreffende verslag/rapport niet bij de 
processtukken (hebben) laten voegen en zal hij de gemaakte kosten ook niet vergoed kunnen krijgen. Kwakmans' voorstellen voor verbetering van de financiële armslag van de verdediging en de kritiek uit de literatuur op het huidige wettelijke systeem zijn niet in het wetsvoorstel verwerkt.

\section{Kwaliteitsborging van deskundigenonderzoek in het wetsvoorstel}

Een belangrijk onderdeel van de voorstellen dat de minister wel heeft overgenomen, is de kwaliteitsborging, onder andere de registratie en protocollering van deskundigenonderzoek. In de huidige wettelijke regeling is de inschakeling van bepaalde deskundigen en de uitvoering van bepaald deskundigenonderzoek uitvoerig vastgelegd. Men leze art. 15la ev. en 195a ev. Sv. (DNA-vergelijkend onderzoek), alsmede de regels inzake bloedalcoholonderzoek en - in mindere mate - art. $37 \mathrm{ev.} \mathrm{Sr.} \mathrm{(terbeschikkingstel-}$ ling). Ook bestaat reeds de 'vaste gerechtelijke deskundige'. Een vaste gerechtelijke deskundige is een deskundige die eenmaal door het gerechtshof in welks ressort de deskundige woont, beëdigd wordt (art. $228 \mathrm{~Sv}$.). Die deskundige hoeft dan niet telkens voor elk onderzoek dat hij of zij verricht of elke verklaring die hij of zij aflegt, opnieuw te worden beëdigd. De praktijk van de juridische figuur van de vaste gerechtelijke deskundige kan men bekritiseren omdat de wet en praktijk niet voorzien in een stelselmatige herbeoordeling van de deskundigheid van de vaste gerechtelijke deskundigen en/of de methoden die dergelijke deskundigen hanteren.

Voor de aanvullingen ten aanzien van de kwaliteitsborging ziet men ten eerste concept-art. 51i Sv. lid 4 Sv. Het artikel maakt gewag van een AMvB die regels zal stellen over de kwalificaties waarover bepaalde deskundigen moeten beschikken en over de wijze waarop in overige gevallen de specifieke deskundigheid van die personen kan worden bepaald of getoetst. Het betreft de hierboven al genoemde concept-AMvB. Voorts voorziet het voorgestelde art. $51 \mathrm{k}$ in de invoering van een landelijk register van gerechtelijke deskundigen (het Nederlands Register Gerechtelijke Deskundigen, NRGD). Aan dat register wordt hard gewerkt. Ook voor civiele zaken wordt aan een dergelijk register gewerkt. Het is de bedoeling van de wetgever dat het register voor deskundigen in civiele zaken uiteindelijk 'opgaat' in het NRGD. Daarnaast codificeert art. 511 Sv. de rechtspraak van de Hoge Raad inzake deskundigenbewijs, met name de vraagpunten die de Hoge Raad 
formuleerde in het arrest inzake de orthopedische schoenmaker. ${ }^{4}$ Uit dat arrest volgt dat, indien de verdediging met kracht van argumenten de deskundigheid van een eerder benoemde deskundige betwist, de rechter - als hij het verslag of de verklaring van de bekritiseerde deskundige toch voor het bewijs gebruikt - moet aangeven te hebben onderzocht of die deskundigheid zich mede uitstrekt tot het onderzoek en de analyse waarvoor hij is benoemd, volgens welke methode hij zijn onderzoek heeft uitgevoerd, waarom hij deze methode betrouwbaar acht, alsmede in hoeverre hij in staat is deze methode vakkundig toe te passen. De codificatie in onderhavig wetsvoorstel gaat zelfs verder dan de eisen van de Hoge Raad omdat het van de deskundige als uitgangspunt verlangt dat hij de aangegeven vraagpunten in zijn verslag opneemt (art. 51k), dus ook zonder betwisting vooraf. Bovendien leidt de invoering van de genoemde concept-AMvB ertoe dat de rechter ambtshalve een 'kwaliteitscontrole' dient uit te voeren indien hij een deskundige benoemt die niet is geregistreerd (art. 13 concept-AMvB).

Het wetsvoorstel rept niet van het recht op tegenonderzoek, hoewel de minister in art. 150a lid 3 de deur openhoudt. Men kan zich afvragen of het noodzakelijk is dat de wet criteria voor het toekennen van een dergelijk recht bevat omdat de Hoge Raad in 2005 een aantal criteria heeft gegeven waarmee procesdeelnemers - voor zover ik heb vernomen - tamelijk goed uit de voeten kunnen.

Naar mijn mening is het verstandig geweest van de wetgever om de wettelijke regeling van deskundigen preciezer te maken. De kritiek betrof de wijze waarop deskundigen in het Nederlandse strafproces worden ingeschakeld, de wijze waarop zij worden gehoord en de wijze waarop rechters deskundigenverklaringen en -verslagen voor hun beslissingen (bewezenverklaring, vrijspraak, (on)toerekeningsvatbaarheid) gebruiken. Het in te voeren registratieen protocolleringssysteem verscherpt ongetwijfeld de controle op de deskundigheid van de in te schakelen 'informatieverschaffers', op de door 'deskundigen' te hanteren methoden en op de wijze waarop zij daarover rapporteren. Ongetwijfeld is de controle vooraf scherper dan in het geval van de huidige vaste gerechtelijke deskundige, wiens benoeming vooral lijkt af te hangen van ervaring. Een kwaliteitscontrole als die waarin de conceptAMvB voorziet, kennen we naar mijn weten niet ten aanzien van de huidige vaste gerechtelijke deskundige. Voorts maakt het systeem het voor proces- 
deelnemers waarschijnlijk gemakkelijker om snel tot een beslissing te komen welke deskundige zij willen inschakelen en waarom. Enkele kanttekeningen zijn hier echter op hun plaats. ${ }^{5}$

\section{Kanttekeningen bij de kwaliteitsborging}

Het in te voeren registratiesysteem voorziet in een fors aantal kwaliteitscriteria waaraan de deskundige die zich wil laten registeren moet voldoen (zie de opsomming in art. 13 van de concept-AMvB). Nadat een deskundige aan die voorwaarden heeft voldaan en door het College voor de gerechtelijke deskundigen is geregistreerd, geldt de registratie voor vier jaar (art. 18 concept$\mathrm{AMvB}$ ). Daarna kan de deskundige zich laten herregisteren, waarna door het College gecontroleerd dient te worden of de deskundige nog steeds aan de kwaliteitscriteria voldoet. Men mag hopen dat die herregistratie niet tot een routinecontrole door het College verwordt en dat het College de criteria telkens zeer kritisch hanteert. Het is louter een waarschuwing, geen vrees. Diezelfde waarschuwing geldt voor de wijze waarop rechters en andere procesdeelnemers de deskundigheid en de door de geregistreerde deskundige te hanteren of gehanteerde methoden benaderen. Dat één en ander is geregistreerd, wil niet zeggen dat men kritiekloos de aangereikte informatie tot zich moet nemen. Afhankelijk van de in de concrete zaak bestaande feiten en omstandigheden, dient er ruimte te zijn voor een kritische benadering van de door de geregistreerde deskundige aangereikte informatie, bijvoorbeeld via een kritische ondervraging en/of contra-expertise, en tevens een motivering van de rechterlijke beslissing waartoe die kritische benadering heeft geleid.

Dat brengt mij op een te onderscheiden punt, de vraag in hoeverre rechters en andere procesdeelnemers kennis moeten hebben van de wetenschap(pelijke kennis) of techniek waarover de (geregistreerde) deskundige verklaart of rapporteert. Mijns inziens dienen de juristen die de deskundige kennis aangereikt krijgen en - vooral - daarover een oordeel moeten geven én dat oordeel moeten motiveren, meer kunnen doen dan tevreden vaststellen dat de deskundige is geregistreerd en dat de deskundige in staat is de methode vakkundig toe te passen. Moet de betrokken jurist dan een 'amateur scientist' worden zoals een Amerikaanse rechter verzuchtte na lezing van de

5 Zie bijvoorbeeld de kritiek van Prof. R.D. Gill e.a. in hun brief aan de Koninklijke Nederlandse Academie voor Wetenschappen (KNAW) van 4 mei 2008 Zie voor de inhoud: http://www.elsevier.nl/artimg/200805/brief_KNAW.pdf. 
bekende uitspraak van het Supreme Court in Daubert versus Dow Merrill? De waarheid ligt ergens in het midden. De invoering van een registratie- en protocolleringssysteem is vast en zeker een verbetering ten opzichte van het huidige, maar zij is niet afdoende. Rechters en andere in het (straf)proces betrokken juristen zullen (wat ik hier maar noem) 'kritische massa' moeten krijgen. Zij zullen meer kennis moeten vergaren over kennis- en wetenschapsfilosofie. Hoe komt kennis en wetenschap tot stand? Hoe worden die kennis en wetenschap naar de 'buitenwereld' gecommuniceerd? Hoe weet de deskundige dat hij weet wat hij zegt? Basiskennis van een aantal meer of minder vaak in het (straf)proces toegepaste wetenschappen en technieken, gecombineerd met de genoemde kritische massa zouden ertoe kunnen leiden dat advocaten, officieren van justitie en rechters kritische en voor de 'materiele waarheidsvinding' relevante vragen kunnen stellen en kunnen uitleggen waarom zij bepaalde door al dan niet geregistreerde deskundigen aangereikte informatie voor hun beslissingen wel of niet kunnen gebruiken. Dit komt het functioneren en de legitimiteit van het strafproces ten goede. 